Lucía Fox: Ayer es nunca jamás (colección de dramas). Lima: Editorial Salesiana, 1980.

Desde el siglo XIX, las escritoras peruanas se han caracterizado en numerosas ocasiones por ser fieles exponentes de las condiciones sociales de su país. Encontramos entre ellas a Clorinda Matto de Turner, Mercedes Cabello de Carbonera y, vinculada directamente a esta tradición de denuncia social, situamos a Lucía Fox: poeta, dramaturga, cuentista y crítica literaria.

La presente colección Ayer es nunca jamás consta de ocho dramas: La santa comunidad, Metamorfosis, El perfil desnudo, iAh! iMujerisima!, Ayer es nunca jamás, El hombre que ríe, El loco inquisidor y Escalas. Una temática consistente, abordada desde una perspectiva social, domina el conjunto de estas piezas teatrales: el encasillamiento del individuo por una sociedad burguesa, oprimente, que imposibilita el diálogo y la comunicación.

No cabe duda de que Lucía Fox tiene una predilección especial por el personaje femenino, y a través de él, plantea con despiadada claridad los problemas que afectan a la mujer, especialmente en la sociedad latinoamericana. Estas protagonistas anhelan una identidad propia y no existir como un instrumento condicionado por la clase social, la familia, el esposo, etc.

En las dos primeras obras, La santa comunidad y Metamorfosis, el intento de liberación y desarrollo personal se aborta. La santa comunidad, como el título tan bien lo sugiere, es un refugio, poderoso claustro que pretende «proteger» a las novicias de las vicisitudes del mundo moderno. El fanatismo religioso actúa como una fuerza opresora, un espacio cerrado que aprisiona a la mujer y sublima su sexualidad. En Metamorfosis, el encasillamiento de roles es tajante. Rebeca abandona toda posibilidad de una vida propia para convertirse en la esposa ideal, la abnegada mujer, un fantasma revestido por la imagen del esposo.

En Ayer es nunca jamás y El perfil desnudo observamos una lucha por liberarse de las normas colectivas. Por primera vez aparecen heroínas rebeldes que rompen lo establecido, pero a la vez se someten a nuevas normas, también asfixiantes. La señora Consuelo, de $E l$ perfil desnudo, se dedica solamente a su profesión, convirtiéndose en prisionera incapaz de integrarse a una vida múltiple. $Y$ así queda atrapada en un extremismo enajenador: «Ahora... al fin... comienzo a verme como un ser inválido... incapaz de salir adelante en ese ruido de las fieras humanas... Sí, me siguen... Te digo que me asedian... (histéricamente)» 
(p. 93). Teresa, en Ayer es nunca jamás, llega al escape final, el suicidio, para rebelarse contra un impuesto matrimonio que limita a la mujer.

Dentro de estos seres conflictivos, una nota de cambio y esperanza se trasluce a través de Matilde, personaje de $E l$ perfil desnudo, que logra independizarse por medio del divorcio, y así la posibilidad de liberarse contra un medio retrógrado. Lupe Tovar es, en iAh! iMujerísima!, una posibilidad nueva, una mujer que afirma su individualismo; ocupa un puesto político de importancia y no desmaya ante crisis emocionales, rompiendo con la tan aceptada tradición femenina de evadir responsabilidades ante una crisis sentimental.

El foco principal de estas obras reside en el tema, aunque la rapidez y claridad del diálogo, las acotaciones, lucen una técnica dramática cuya destreza se aprecia especialmente en las tres últimas obras: El hombre que rie, El loco inquisidor y Escalas. En estas fantasías dramáticas, donde lo real y lo irreal se superponen, funden y confunden, Lucía Fox explora el problema de la incomunicación,

En $E l$ hombre que ríe, Víctor, incapaz de integrarse afectivamente con los seres que lo rodean, enloquece. Muere de una enfermedad desconocida: la risa. Con este aparente absurdo, el resto de los personajes queda atrapado por el recuerdo del hombre que ríe, cuya voz se convierte en una alucinación que distorsiona y persigue. Gabricla, al liberarse de su propia conciencia y sus obsesiones, se salva: «Vengan... les aseguro nadie ríe. El hombre que reía ya nos dejará volver a nacer» (p. 199). La risa, entre angelical y diabólica, sugiere varias interpretaciones. Tal vez es el producto de la soledad, que condena al hombre contemporáneo a morir riéndose.

El loco inquisidor configura la misma problemática de la incomunicación, pero esta vez el loco calato representa una institución: la Iglesia católica, vive solitario en una casona antigua. Una pareja humilde y joven decide entrar en este mundo prohibido, y se sumerge en tuna especie de pasado mítico, donde el loco los confunde con otra pareja, los condena y juzga con las reglas de la Inquisición. ¿Es el loco una metáfora de los santuarios del planeta, donde los peregrinos son juzgados por fuerzas ciegas, máscaras de falsos racionalismos?

Escalas es, tal vez, la obra más compleja de la colección. Es difícil aclarar las fuerzas ocultas que dominan la secta de falsos místicos envueltos en un erotismo que sólo se desencadena ante el horror. La confusión permea en la obra, tanto en el caos interno de los personajes como en la situación externa del país y la sociedad que los rodea. Se crea la típica dicotomía entre el bien y el mal, el explotador y el explotado, y los problemas no resueltos insinúan la decadencia humana.

Ayer es nunca jamás, fascinante colección de dramas que explora con maestría las obsesiones universales del ser. Tanto en la lectura como en el posible escenario, Lucía Fox es lúcida. Proyecta problemas que implican un enfrentamiento continuo con los sucesos y las actitudes de la realidad circundante: una sociedad dividida.

\section{Indiana University}

MARJoRIE Agosin 